[Original]

\title{
Usefulness of Fibrinogen/Fibrin Degradation Products Value in Differential Diagnosis Between Acute Ischemic Stroke and Acute Aortic Dissection
}

\author{
Shun-ichi Ninei ${ }^{*}$, Hideaki AraI, Takayuki Uchida, Ayako KanaZawa, Takeru Endo, Ken OtsujI, \\ Nobuya Harayama, Keiji Aibara and Masayuki Kamochi
}

Intensive Care Unit, University Hospital, University of Occupational and Environmental Health, Japan. Yahatanishi-ku, Kitakyushu 807-8556, Japan

\begin{abstract}
A post-marketing surveillance study reported fatalities following tissue plasminogen activator administration in acute aortic dissection (AAD) with the symptoms of acute ischemic stroke (AIS) patients. Therefore, it is important to discriminate AAD from AIS. The present study aimed to investigate whether fibrinogen/fibrin degradation products (FDP) value can be useful in differential diagnosis between AAD and AIS. The study group comprised $20 \mathrm{AAD}$ patients (10 men and 10 women; age $63.9 \pm 13.6$ years) and 159 AIS patients ( 91 men and 68 women; age $74.2 \pm 10.6$ years) who were transported to our hospital from 2007 to 2012 . The AAD cases were further divided into patent-type AAD and thrombosed-type AAD. FDP values were significantly higher in the AAD group than in the AIS group (18.15 [5.2-249.9] $\mu \mathrm{g} / \mathrm{m} l$ vs. 2.3 [1.5-4.45] $\mu \mathrm{g} / \mathrm{ml} ; P<0.001)$. In AAD groups, FDP values were significantly higher in the patent-type AAD group $(\mathrm{n}=9)$ than in the thrombosed type AAD group $(\mathrm{n}=11)(293.2 \mu \mathrm{g} / \mathrm{m} l$ $[63.1-419.6 \mu \mathrm{g} / \mathrm{m} l]$ vs. $5.6 \mu \mathrm{g} / \mathrm{ml}[3.8-7.9 \mu \mathrm{g} / \mathrm{m} l]$. FDP values were significantly higher in patients with AAD than in those with AIS, especially those with patent-type AAD compared with AIS patients. High FDP values may be a useful marker for differential diagnosis between patent-type AAD and AIS.
\end{abstract}

Keywords : acute aortic dissection, acute ischemic stroke, fibrinogen/fibrin degradation products.

(Received December 28, 2017, accepted May 14, 2018)

\section{Introduction}

Intravenous thrombolysis is the only approved treatment for acute ischemic stroke (AIS) within 4.5 hours from symptom onset. However, because of the narrow time window, the underlying pathogenesis of stroke may not be examined. Therefore, careful selection of appropriate candidates may not be performed. According to the results of a 2007 survey on the use of tissue plasminogen activator (t-PA; a thrombolytic agent) in Japan, 10 patients died after t-PA was used in AIS patients who had acute aortic dissection (AAD) [1]. This suggests that AAD should be discriminated from AIS.

AAD classically presents as sudden, severe chest, back, or abdominal pain. However, there have been several documented cases presenting with atypical features. Imamura et al. showed that painless AAD is not rare, and many patients present with focal neurologic deficits [2]. The diagnosis of AAD has been missed on initial evaluation in up to $38 \%$ of patients, and its diagnosis has first been established at postmortem examinations in up to $28 \%$ of patients [3-5]. These findings suggest that specific markers are required for suspected AAD.

*Corresponding Author: Shun-ichi NiHeI MD, Intensive Care Unit, University Hospital, University of Occupational and Environmental Health, Japan. Yahatanishi-ku, Kitakyushu 807-8556, Japan, Tel +81-93-603-1611, Fax: +81-93-601-3349, E-mail:nihei@med.uoeh-u.ac.jp 
D-dimer is known as a marker of AAD [6, 7]. However, a rapid assay to quantify D-dimer is not currently being used in all emergency hospitals. Indeed, we could not also measure D-dimer in the night time in our hospital, so alternative modality is required. On the other hand, fibrinogen/fibrin degradation products (FDP) are used widely for diagnosis of disseminated intravascular coagulation (DIC) [8]. Nagaoka et al. reported that measurement of FDP may be useful for initial assessment of patients with suspected AAD [9]. We previously reported four AAD patients with high FDP levels accompanied by symptoms of AIS [10]. Therefore, FDP value may be useful for distinction between AIS and AAD. The present study aimed to investigate whether FDP value is useful for differential diagnosis between AAD and AIS.

\section{Methods}

This study was performed in accordance with the principles of the Declaration of Helsinki and was approved by our University Ethics committee (No. H26213). The ethics committee does not require informed consent for retrospective studies, such as this study.

\section{Subjects}

This study was a retrospective study. The study group included 20 patients with AAD (AAD group) who were admitted to the University Hospital, University of Occupational and Environmental Health, Japan. between January 2007 and March 2012 (patients with cardiopulmonary arrest on arrival were excluded). A total of 159 patients with AIS (AIS group) served as the control group.

FDP value is routinely measured in our emergency department at the time of admission. Therefore, FDP measurements were available for patients presenting with suspected AAD or AIS.

\section{Diagnosis of Acute Aortic Dissection or Acute Ischemic Stroke}

The diagnosis of AAD was defined by contrast enhanced computed tomography. Standard guidelines [11] were used to diagnose AAD. AAD cases were divided into two categories. One category included those with a patent false lumen (patent-type AAD), which was defined as the presence of an intimal flap separating the true and false lumen. The false lumen was identified by opacification of contrast media including partial thrombosis [12]. The other category included those with complete thrombosis of a false lumen (thrombosed-type AAD), which was defined as the presence of complete thrombosis of the false lumen [13]. Definitive diagnosis of AIS was performed according to magnetic resonance imaging or computed tomography [14].

\section{Data collection}

We investigated blood pressure and past medical history, which were recorded on admission, in each group based on hospital clinical records. We measured the diameter of the superior mediastinum on chest X-ray in each patient. The diameter of the superior mediastinum was assumed to be the total of the diameter from the midline to the superior vena cava line and the diameter from the midline to the aortic arch. We compared laboratory data, including white blood cell(WBC) $(/ \mu l)$, platelets $\left(10^{3} / \mu l\right)$, C-reactive protein $(\mathrm{CRP})(\mathrm{mg} / \mathrm{d} l)$, the international normalized ratio (INR), fibrinogen $(\mathrm{mg} / \mathrm{d} l)$, activated partial thromboplastin times (APTT), and FDP $(\mu \mathrm{g} / \mathrm{m} l)$, between the AAD group and the AIS group.

\section{Statistical analysis}

Data are presented as the mean value \pm standard deviation, median, and percentile range. Statistical analysis was performed with statistical software (StatMate IV, ATMS Co., Ltd. Tokyo). The chi-squared test was used for comparison of discrete variables. The Student's $t$ test and Mann-Whitney test were used for comparison between the AAD and AIS groups. The Kruskal-Wallis test was used to compare FDP levels in three groups (patent-type AAD group, thrombosed-type AAD group, and AIS group). $P<0.05$ was considered statistically significant. Receiver operating characteristic (ROC) curve analysis was performed to determine optimal FDP cutoff value defined as the value with highest sensitivity (1-specificity). We determined FDP cutoff value to differentiate all AAD patients or patent-type AAD patients from those with AIS. The area under the ROC for all AAD patients or patent-type AAD patients versus AIS patients was also calculated at each cutoff value. 


\section{Results}

Age, gender, and past history

There were 159 patients (91 men and 68 women) in the AIS group. There were 20 patients ( 10 men, 10 women) in the AAD group. The mean age was significantly higher in the AIS group than in the AAD group ( $74.2 \pm 10.6$ vs $63.9 \pm 13.6$ years, respectively; $P<0.01$ ). There were no significant differences in other baseline characteristics between the two groups (Table 1).

\section{Blood pressure and diameter of the superior mediastinum}

There was no significant difference in blood pressure between the two groups. The diameter of the su-

Table 1. Characteristics of the acute aortic dissection and acute ischemic stroke groups

\begin{tabular}{lccc}
\hline Baseline characteristics & $\begin{array}{c}\text { AAD } \\
\mathrm{n}=20\end{array}$ & $\begin{array}{c}\text { AIS } \\
\mathrm{n}=159\end{array}$ & $P$ \\
\hline Age & $63.9 \pm 13.6$ & $74.2 \pm 10.6$ & $P<0.01$ \\
$\quad \begin{array}{l}\text { Male } \\
\text { Past history }\end{array}$ & & & \\
Number of hypertension & $11(50.0)$ & $91(57.2)$ & N.S. \\
Number of diabetes mellitus & $1(5.0)$ & $36(22.6)$ & N.S. \\
Number of hyperlipidemia & $3(15.0)$ & $7(4.4)$ & N.S. \\
Number of heart disease & $4(20.0)$ & $54(34.0)$ & N.S. \\
others & $6(30.0)$ & $37(23.2)$ & N.S. \\
\hline
\end{tabular}

Values are mean \pm standard deviation or the number of patients, N.S.: not significant, AAD: acute aortic dissection, AIS: acute ischemic stroke, ( ): \% perior mediastinum on chest X-ray was significantly enlarged in the AAD group compared with the AIS group $(9.66 \mathrm{~cm}$ [8.69-10.34 cm] vs $7.91 \mathrm{~cm}$ [7.21$8.67 \mathrm{~cm}$ ], respectively; $P<0.001)$.

\section{Laboratory data}

There were no significant differences in CRP levels and platelet count between the two groups. The WBC count was significantly higher in the AAD group than in the AIS group $(11,200 / \mu l[8,800-124,500 / \mu l]$ vs. $7,100 /$ $\mu l[5,900-9,000 / \mu l]$; respectively; Table 2). There were no significant differences in the INR, fibrinogen, and APTT between the two groups.

\section{Comparison of fibrinogen/fibrin degradation products value}

Fibrinogen/fibrin degradation products (FDP) value was significantly higher in the AAD group than in the AIS group $(18.15 \mu \mathrm{g} / \mathrm{ml}[5.2-249.9 \mu \mathrm{g} / \mathrm{m} l]$ vs. $2.3 \mu \mathrm{g} /$ $\mathrm{m} l[1.5-4.45 \mu \mathrm{g} / \mathrm{m} l], P<0.001$; Table 2). We classified AAD into patent-type AAD and thrombosed-type AAD groups. FDP value was significantly higher in the patent-type AAD group $(n=9)$ than in the thrombosed type AAD group $(\mathrm{n}=11)\left(293.2 \mu \mathrm{g} / \mathrm{ml}\left[63.1^{-}\right.\right.$ $419.6 \mu \mathrm{g} / \mathrm{m} l]$ vs. $5.6 \mu \mathrm{g} / \mathrm{ml}[3.8-7.9 \mu \mathrm{g} / \mathrm{ml}], P<0.001)$. There was no significant difference in FDP value between the thrombosed-type AAD group and the AIS group (Fig. 1).

Table 2. Laboratory data on admission in the acute aortic dissection (AAD) and acute ischemic stroke (AIS) groups

\begin{tabular}{|c|c|c|c|c|c|c|c|}
\hline \multirow[t]{2}{*}{ Statistics quartile } & \multicolumn{3}{|c|}{ AAD $n=20$} & \multicolumn{3}{|c|}{ AIS $n=159$} & \multirow[t]{2}{*}{$P$} \\
\hline & $25 \%$ & $50 \%$ & $75 \%$ & $25 \%$ & $50 \%$ & $75 \%$ & \\
\hline Systolic bloodpressure (mmHg) & 110.3 & 156.5 & 192.5 & 145.0 & 164.0 & 182.0 & N.S. \\
\hline Diastolic blood pressure (mmHg) & 56.0 & 84.5 & 110.3 & 75.0 & 89.0 & 100.0 & N.S. \\
\hline \multicolumn{8}{|l|}{ Blood collection data } \\
\hline White blood cell counts $\left(\times 10^{3} / \mu l\right)$ & 8.8 & 11.2 & 12.5 & 5.9 & 7.1 & 9.0 & $P<0.001$ \\
\hline Platelet $\left(\times 10^{3} / \mu l\right)$ & 16.4 & 18.9 & 22.4 & 16.4 & 16.4 & 22.9 & N.S. \\
\hline C-reactive protein $(\mathrm{mg} / \mathrm{d} l)$ & 0.1 & 0.2 & 0.5 & 0.1 & 0.1 & 0.3 & N.S. \\
\hline Prothrombin time-international normalized ratio & 1.0 & 1.1 & 1.1 & 1.0 & 1.0 & 1.1 & N.S. \\
\hline Activated partial thromboplastin time (s) & 25.8 & 27.0 & 29.7 & 24.2 & 26.3 & 28.7 & N.S. \\
\hline Fibrinogen $(\mathrm{mg} / \mathrm{d} l)$ & 198.0 & 258.0 & 359.5 & 244.5 & 291.0 & 333.0 & N.S. \\
\hline Fibrinogen/fibrin degradation products & 5.2 & 18.2 & 249.9 & 1.5 & 2.3 & 4.5 & $P<0.001$ \\
\hline \multicolumn{8}{|l|}{ Chest X-ray } \\
\hline Superior mediastinum diameter $(\mathrm{cm})$ & 8.7 & 9.7 & 10.3 & 7.2 & 7.9 & 8.7 & $P<0.001$ \\
\hline
\end{tabular}

N.S.: not significant 


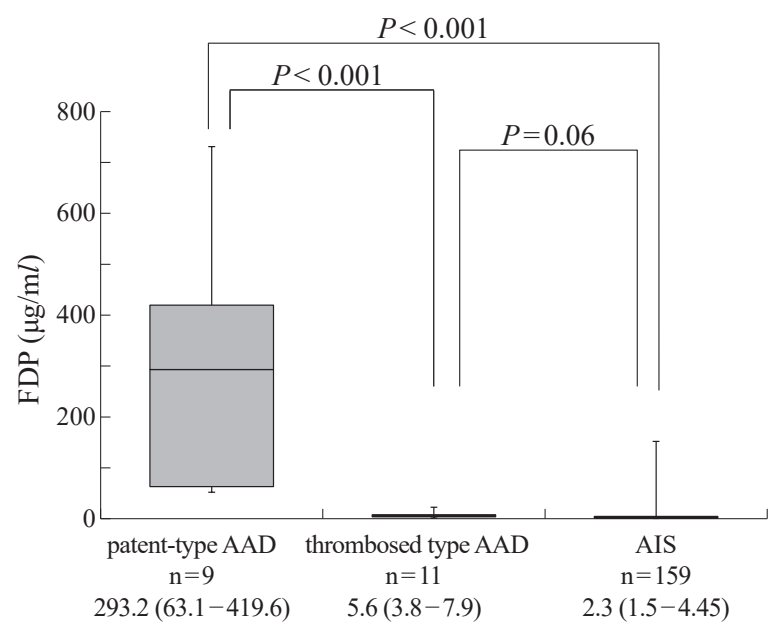

Fig. 1. Comparison of fibrinogen/fibrin degradation products (FDP) value between the acute aortic dissection (AAD) and acute ischemic stroke (AIS) groups.

\section{Receiver operating characteristic curve analysis}

Receiver operating characteristic (ROC) curve analysis showed that FDP was predictive of diagnosis of AAD (area under the ROC curve: $0.87 \pm 0.03, P<0.05$ ). The sensitivity and specificity were $75 \%$ and $81 \%$, respectively, at a cutoff value of $5.6 \mu \mathrm{g} / \mathrm{ml}$. The area under the curve for patent-type AAD was $0.95 \pm 0.04$. The sensitivity and specificity were $100 \%$ and $97.4 \%$, respectively, at a cutoff value of $52.4 \mu \mathrm{g} / \mathrm{ml}$ (Fig. 2).

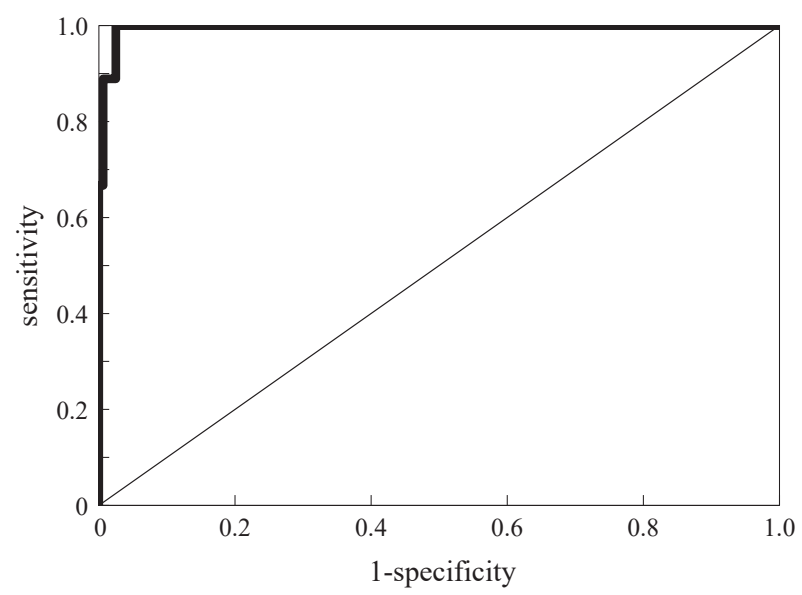

Fig. 2. Comparison of fibrinogen/fibrin degradation products value between the thrombosed-type acute aortic dissection, patent-type acute aortic dissection, and acute ischemic stroke groups.

\section{Discussion}

AIS treatment was dramatically changed by approval of tissue plasminogen activator treatment. Intravenous thrombolysis is the only approved treatment for AIS within $4.5 \mathrm{~h}$ from symptom onset. However, approximately $30 \%$ of patients with Stanford type A dissection show initial neurologic symptoms [15]. For AIS patients who are eligible for thrombolysis, AAD is particularly challenging because of the difficulty of diagnosis within a narrow time window and the high risk of life-threatening complications for thrombolysis. Therefore, markers are required for suspected AAD. The incidence of decreased blood pressure is unclear, but caution is needed in patients who do not have especially high blood pressure in the acute stage, despite a history of hypertension [16]. In our study, there was no significant difference in blood pressure between the AAD and AIS groups. Therefore, blood pressure may not be discriminate between AAD and AIS. The diameter of the superior mediastinum was significantly enlarged in the AAD group compared with the AIS group. Thus, the superior mediastinum diameter on chest X-ray maybe a useful measure. However, previous studies have reported that the rate of enlargement of the diameter of the superior mediastinum on chest X-ray in AAD is $10 \%-29 \%$ [17, 18]. Therefore, chest X-ray alone cannot be used for discrimination. Carotid ultrasonography may also be useful for discrimination, as it can be used to visualize $\mathrm{AAD}[19]$. However, this is difficult to implement in actual clinical practice.

In this study, the WBC count was significantly higher in the AAD group than in the AIS group. The systemic inflammatory reaction in AAD is provoked by acute aortic injury and is reflected in WBC count [20]. WBC count may be useful for different diagnosis between $\mathrm{AAD}$ and AIS. However, because we cannot classify infection disease by WBC count independently, we may not be able to use WBC count as a marker of AAD independently.

D-dimer is known marker of AAD [6, 7]. However, a rapid assay to quantify D-dimer is not currently being used in all emergency hospitals. Therefore, an alternative modality is required to determine $\mathrm{AAD}$. In the present study, FDP value was significantly higher in the 
AAD group compared with AIS group. Nagaoka et al. reported that FDP may be useful for distinguishing acute myocardial infarction with AAD [9]. Moreover, we classified the AAD group into a patent-type AAD group and a thrombosed-type AAD group, and compared FDP value between the three groups. FDP value in the patent-type $\mathrm{AAD}$ group was significantly higher than those in the AIS group and thrombosed-type AAD group. However, there was no difference in FDP value between the thrombosed-type AAD group and the AIS group. The difference in FDP between patent-type AAD and thrombosed-type AAD relates to the absence of continuous flow communication through an intimal tear in thrombosed-type AAD. A false lumen that becomes enlarged rarely crushes the true lumen in thrombosedtype AAD. This enlargement does not usually lead to branch obstruction in thrombosed-type AAD. Thus, the incidence of AIS may be low in thrombosed-type AAD compared with patent-type AAD. Indeed, Kaji et al. reported that the incidence of AIS was significantly higher in patent-type AAD [21]. These findings suggested that FDP value may be useful for initially assessing patients for discrimination between $\mathrm{AAD}$, especially patent-type AAD, and AIS. About extension of aortic dissection in this study, Stanford A type cases were 12 examples and Stanford B type cases were 8 examples in AAD group. It is not clear that FDP value is different by difference of aortic dissection type. We could not also examine change of FDP value by the time course due to retrospective study. There is a need for further study.

\section{Study limitations}

This was a retrospective analysis of a single center, which may have introduced some bias in the patients. A larger number of cases is required in a future study. The mechanism underlying the increased FDP value in patent-type AAD compared with thrombosed-type AAD is also unclear. Further studies are required to clarify this mechanism and assess strategies for differential diagnosis between AAD and AIS.

Painless AAD patients often present with a disturbance of consciousness or a neurologic deficit, so it is preferable to incorporate the description about lack of symptomatic information. However, it is impracticable to evaluate symptoms due to retrospective study.

\section{Conclusion}

We found that FDP value was significantly higher in patients with $\mathrm{AAD}$, especially those with patent-type AAD compared with AIS patients. High FDP value may be a useful marker for differential diagnosis between patent-type AAD and AIS.

\section{Conflict of Interest}

The authors declare no conflicts of interest.

\section{References}

1. Nakagawara J (2008): A discussion on reported 10 cases given alteplase and author's series of acute ischemic stroke with acute aortic dissection. Jpn J Stroke 30: 452-454 (in Japanese)

2. Imamura H, Sekiguchi Y, Iwashita T et al (2011): Painless acute aortic dissection. -Diagnostic, prognostic and clinical implications ${ }^{-}$. Circ J 75: 59-66

3. Bickerstaff LK, Pairolero PC, Hollier LH, Melton LJ, Van Peenen HJ, Cherry KJ, Joyce JW \& Lie JT (1982): Thoracic aortic aneurysms: a population-based study. Surgery 92: 1103-1108

4. Spittell PC, Spittell JA Jr, Joyce JW, Tajik AJ, Edwards WD, Schaff HV \& Stanson AW (1993): Clinical features and differential diagnosis of aortic dissection: experience with 236 cases (1980 Through 1990). Mayo Clin Proc 68: 642-651

5. Hagan PG, Nienaber CA, Isselbacher EM et al (2000): The international registry of acute aortic dissection (IRAD): new insights into an old disease. JAMA 283: 897-903

6. Eggebrecht H, Naber CK, Bruch C, Kröger K, von Birgelen C, Schmermund A, Wichert M, Bartel T, Mann K \& Erbel R (2004): Value of plasma fibrin D-dimers for detection of acute aortic dissection. J Am Coll Cardiol 44: 804-809

7. Suzuki T, Distante A, Zizza A et al; IRAD-Bio Investigators (2009): Diagnosis of acute aortic dissection by Ddimer: the international registry of acute aortic dissection substudy on biomarkers (IRAD-Bio) experience. Circulation 119: 2702-2707

8. Gando S, Iba T, Eguchi Y et al (2006): A multicenter, prospective validation of disseminated intravascular 
coagulation diagnostic criteria for critically ill patients: comparing current criteria. Crit Care Med 34: 625-631

9. Nagaoka K, Sadamatsu K, Yamawaki T, Shikada T, Sagara S, Ohe K, Morishige K, Tanaka E \& Tashiro H (2010): Fibrinogen/fibrin degradation products in acute aortic dissection. Intern Med 49: 1943-1947

10. Irifukuhama $Y$, Nihei S, Nagata K, Isa Y, Harayama N, Aibara K \& Kamochi M (2013): Four cases of acute aortic dissection accompanied by symptoms of acute cerebral infarction. JJAAM 24: 351-356 (in Japanese)

11. Erbel R, Alfonso F, Boileau C et al (2001): Diagnosis and management of aortic dissection. Eur Heart J 22: 1642-1681

12. Tsai TT, Evangelista A, Nienaber CA et al (2007): Partial thrombosis of the false lumen in patients with acute type B aortic dissection. N Engl J Med 357: 349-359

13. Tamori Y, Akutsu K, Kasai S et al (2009): Coexistent true aortic aneurysm as a cause of acute aortic dissection. Circ J 73: 822-825

14. Swain S, Turner C, Tyrrell P \& Rudd A (2008): Diagnosis and initial management of acute stroke and transient ischaemic attack: summary of NICE guidance. BMJ 337: a786

15. Gaul C, Dietrich W, Friedrich I, Sirch J \& Erbguth FJ
(2007): Neurological symptoms in type A aortic dissections. Stroke 38: 292-297

16. Matsuo H (2011): Clinical significance and impact of "painless" acute aortic dissection. Circ J 75: 47-48

17. Sullivan PR, Wolfson AB, Leckey RD \& Burke JL (2000): Diagnosis of acute thoracic aortic dissection in the emergency department. Am J Emerg Med 18: 46-50

18. Gregorio MC, Baumgartner FJ \& Omari BO (2002): The presenting chest roentgenogram in acute type A aortic dissection: a multidisciplinary study. Am Surg 68: $6^{-10}$

19. Iguchi Y, Kimura K, Sakai K, Matsumoto N, Aoki J, Yamashita S \& Shibazaki K (2010): Hyper-acute stroke patients associated with aortic dissection. Intern Med 49: 543-547

20. Sugano Y, Anzai T, Yoshikawa T, Satoh T, Iwanaga S, Hayashi T, Maekawa Y, Shimizu H, Yozu R\& Ogawa S (2005): Serum C-reactive protein elevation predicts poor clinical outcome in patients with distal type acute aortic dissection: association with the occurrence of oxygenation impairment. Int J Cardiol 102: 39-45

21. Kaji S, Akasaka T, Horibata Y et al (2002): Long-term prognosis of patients with type A aortic intramural hematoma. Circulation 106 (Suppl 1): I-248-I-252 
急性虚血性脳卒中と急性大動脈解離の鑑別診断におけるフィブリノゲンノフィブリン分解産物の有用性

二瓶 俊一, 荒井 秀明, 内田 貴之, 金澤 綾子, 遠藤 武尊, 尾辻 健, 原山 信也, 相原 啓二, 蒲地 正幸

産業医科大学病院＼cjkstart集中治療部

要旨：急性虚血性脳卒中の症状を有する急性大動脈解離症例に組織プラスミノーゲンアクチベータ(tissue plasminogen activator) を使用し, 死亡に至った事例が報告されている。 それゆえ急性大動脈解離と急性虚血性脳卒中 の鑑別が重要である。本研究ではフィブリノゲン/フィブリン分解産物 (FDP) 值が急性大動脈解離と急性虚血性脳 卒中の鑑別に有用であるかを調査した。研究対象者は, 2007年から 2012年に当院へ搬送された, 20 名の急性大動脈 解離症例 (男性 10 名, 女性 10 名, 平均年齢 $63.9 \pm 13.6$ 歳) および 159 名の急性虚血性脳卒中症例 (男性 91 名, 女性 68 名, 平均年齢74.2 10.6 歳) であった。さらに大動脈解離症例を偽腔開存型急性大動脈解離群と血栓閉塞型大動脈解離 群に分類した. FDP值は急性虚血性脳卒中群と比較し急性大動脈解離群で有意に高くなっていた(18.15 [5.2-249.9］ $\mu \mathrm{g} / \mathrm{m} l$ vs. $2.3[1.5-4.45] \mu \mathrm{g} / \mathrm{m} l, P<0.001)$. 急性大動脈解離症例に打いて, 血栓閉塞型大動脈解離群 $(\mathrm{n}=11)$ と比較し て, 偽腔開存型大動脈解離群 $(\mathrm{n}=9)$ で有意にFDP值が高くなっていた $(293.2 \mu \mathrm{g} / \mathrm{m} l[63.1-419.6 \mu \mathrm{g} / \mathrm{m} l] \mathrm{vs} .5 .6 \mu \mathrm{g} / \mathrm{m} l$ [3.8-7.9 $\mu \mathrm{g} / \mathrm{m} l]$. 結論として, 急性虚血性脳卒中群と比較し急性大動脈解離群, 特に急性虚血性脳卒中と比較し, 偽 腔開存型大動脈解離群でFDP值が有意に高くなっている.FDP值の上昇は急性虚血性脳卒中と偽腔開存型急性大動 脈解離の鑑別に有用なマーカーとなる可能性がある.

キーワード : 急性大動脈解離, 急性虚血性脳卒中, フィブリノゲン/フィブリン分解産物. 